\title{
Genetic Diversity of Schizothorax, Tor, and Mystus spp. in Khyber Pakhtunkhwa, Pakistan: Species of Economic Importance
}

\author{
Muhammad Qayash Khan ${ }^{1,2}$, Muhammad Zubair Anjum², Muhammad Adnan', \\ Abbas Khan', Hafsa Zahid ${ }^{1}$, Javed Nawab ${ }^{4}$, Sher Zaman Safi, \\ Muhammad Ishaq Ali Shah ${ }^{6}$, Atif Kamil ${ }^{7}$ and Abid Ali ${ }^{1 *}$ \\ ${ }^{1}$ Department of Zoology, Abdul Wali Khan University Mardan, Khyber Pakhtunkhwa, \\ Pakistan \\ ${ }^{2}$ Department of Zoology, Pir Mehr Ali Shah Arid Agriculture University, Punjab, \\ Pakistan \\ ${ }^{3}$ Department of Zoology, University of Peshawar, Peshawar Khyber Pakhtunkhwa \\ ${ }^{4}$ Department of Environmental Science, Abdul Wali Khan University Mardan, Khyber \\ Pakhtunkhwa, Pakistan \\ ${ }^{5}$ Interdisciplinary Research Centre in Biomedical Materials (IRCBM), COMSATS \\ Lahore, Pakistan \\ ${ }^{6}$ Department of Chemistry, Abdul Wali Khan University Mardan, Khyber \\ Pakhtunkhwa, Pakistan \\ ${ }^{7}$ Department of Biotechnology Abdul Wali Khan University Mardan.
}

\section{A B S T R A C T}

Among closely related fish species the taxonomic ambiguities arose as a result of morphological similarities which not only conceal the genetic diversity but also pose problems in fisheries management and conservation practices. The purpose of the present study was a molecular characterization of fish species of economic importance belonging to the genus Schizothorax, Tor and Mystus collected from various rivers of Khyber Pakhtunkhwa, Pakistan. The samples were morphologically identified, its mitochondrial DNA was extracted and subjected to molecular characterization by amplifying and sequencing the mitochondrial cytochrome $\mathrm{c}$ oxidase $1(\mathrm{CO})$ gene. The sequencing data revealed rich genetic diversity among fish specimens belonging to the genus Schizothorax. For the genus Tor, as was commonly believed of having two species (Tor putitora and Tor macrolepus), the sequencing data was not in agreement with the morphological identification and hence negated the existence of $T$. macrolepus. The genus Mystus was also found to be comprised of a single species: M. armatus. The COI sequence of M. armatus reported for the first time during this study will be a useful addition to the database. The present study strongly recommends the effectiveness of $\mathrm{COI}$ barcoding for species delineation over the traditional taxonomic methods.

\section{INTRODUCTION}

$\mathrm{P}$ akistan is an agricultural country where majority of the population relies on agriculture products. Agriculture plays a key role in the economy of the country which contributes about $21 \%$ to the total GDP (Azam and Shafique, 2017). The freshwater natural resources of Pakistan in the form of rivers, streams, natural lakes, and dams are valuable and have a great potential for fisheries and aquaculture practices. Generally, freshwater fish

\footnotetext{
* Corresponding author: uop_ali@yahoo.com 0030-9923/2021/0003-1099 \$ 9.00/0

Copyright 2021 Zoological Society of Pakistan
}

species are considered as one of the important and valuable food source across the globe. Freshwater fish fauna of Pakistan is widely distributed and is comprised of 193 fish species of which 43 fish species are endemic (Rafique and Khan, 2012; Khan et al., 2018). The river Indus, its tributaries and many other glacial fed streams constitute an excellent freshwater natural habitat for the survival of about 180 freshwater fish species (Mirza and Mirza, 2014).

The environmental contaminants, habitat degradation, extensive use of insecticides, pesticides and herbicides are among the serious issues for the aquatic biodiversity and its conservation in Pakistan. For instance, atrazine herbicides have significantly affected the hematological and biochemical indices of fishes (Ali et al., 2018). 
The importance of indigenous fish fauna cannot be negated and threats to their habitat and spawning grounds due to anthropogenic and environmental contamination is a well-documented fact. With this in mind, the documentation and accurate identification of fish species are not only required to detect market fraud but also to assist their management and conservation practices. Traditional methods of morphological identification can be misleading and erroneous (Wong and Hanner, 2008). Fish species belonging to the same genus possess remarkable morphological similarities which pose problems in their accurate identification at least for a non-experienced worker (Tahir and Akhtar, 2016).

The fishes included in sub-family Schizothoracine are commonly known as snow trout or Himalayan trout, comprising of 15 genera and over 100 species across the world (Mir et al., 2013). The taxonomy of snow trout has been studied extensively (McClelland, 1839; Hora, 1936; Jhingran, 1991; Kullander et al., 1999). The taxonomic ambiguity among species of the genus Schizothorax due to their remarkable morphological similarities has been well documented (Chandra et al., 2012; Mir et al., 2013) For example, Shizothorax plagiostomus is very similar to Shizothorax labiatus, both species are syntopic and are therefore usually misidentified. On the other hand, Tor putitora (Golden Mahaseer) is an expensive and national fish of Pakistan, which is distributed throughout South and South East Asia. A total of twenty species have been identified and recognized within this genus across Asia, with a wide distribution from Himalayan to Malaysia and Indonesia (Chen and Yang, 2004). The morphological similarities in the species belonging to the genus Tor have been reported and Tor yingjiangensis has long been misidentified as an allopatric species, $T$. putitora Hamilton, 1822 (ZiMing and JunXing, 2004). In Khyber Pakhtunkhwa (KP) Pakistan, before this study, the morphological identification of the species of the genus Tor led us to believe that it was comprised of two species: T. putitora and Tor macrolepus.

Species belong to the genus Mystus are small to medium size and are distributed throughout Asia. The distribution range of Mystus armatus extended to Myanmar and Bangladesh (Hora, 1931; Jayaram and Sanyal, 2003). Previous studies have confirmed the existence of 44 species belonging to the genus Mystus (Jayaram and Sanyal, 2003; Ferraris, 2007). Prior to this study, M. armatus in Pakistan was identified on the basis of morphological characters and it was one of the least studied species. Molecular characterization was therefore essential to confirm if there is any genetic diversity. In such scenarios, where morphological identification fails or is misleading, molecular approaches have been proved useful and an effective tool for exact and flawless identification at species level (Arnot et al., 1993; Floyd et al., 2002).

Molecular based approach is a powerful tool for species identification as it can be applied to organisms at any stage of their life from egg to adult or even to their remains without taking into consideration their morphological characters (Kochzius, 2009). Certain mitochondrial genes are well characterized and are the promising markers for exact identification of fish species in contrast to the nuclear genes (Hubert and Hanner, 2015). The reason being that mitochondrial DNA is only 15-20 $\mathrm{Kb}$ in size, present in high copy number and is in a more stable circular form. The properties of mitochondrial DNA including only $15-20 \mathrm{~Kb}$ in size, presenting in high copy number and in a more stable circular form not only help in efficient extraction but also eases the downstream analysis (Hubert et al., 2008). The application of COI barcoding for the identification of freshwater and marine fishes has been demonstrated and proved effectively (Wang et al., 2012).

The economically important fish species of the genus Schizothorax are abundantly found in cold and semi-cold waters while those of Tor and Mystus genera are confined to semi-cold and warm waters of Pakistan. Very little is known about their genetic diversity, therefore, the study was aimed to investigate the genetic diversity at species level in the genus Schizothorax captured from District Kohistan while Tor and Mystus from District Mardan, KP, Pakistan.

\section{MATERIALS AND METHODS}

A total of $540 \mathrm{~S}$. plagiostomus were collected from different localities along river Indus in District Kohistan (35'14'60.00" N, 73²9'59.99” E) during 2016. On the other hand, $352 \mathrm{~T}$. putitora and $180 \mathrm{M}$. armatus were collected from different localities along Balar Stream in District Mardan (34³4'82.50” N, 72²7'28.20” E) during 2017. Fish specimens across all localities were collected by using 5-panels of gill net $6 \times 25$ feet (mesh size $1 \mathrm{~cm}$, $1.5 \mathrm{~cm}, 2 \mathrm{~cm}, 2.5 \mathrm{~cm}$ and, $3 \mathrm{~cm}$ ) during the first week of each month. The latitude and longitude of the collection stations were extracted from Google Earth Pro and the site map was developed by using the ArcGIS version 10.3.1 (Fig. 1). Collected fish species were carefully identified on the basis of morphology by using the available taxonomic keys (Jayaram, 1981; Kullander et al., 1999). The dorsal finrays (D), pectoral finrays (P), ventral finrays (V), anal finrays (A) and lateral line scales were counted.

DNA was separately extracted from the muscle tissues of fish samples collected from each station using a genomic DNA extraction kit following the manufacturer's instructions (Thermo Scientific GeneJET). Shortly, muscle 
tissue $(20 \mathrm{mg})$ were grinded gently by a sterilized mortar and pestle, placed in an Eppendorf tube, suspended in 180 $\mu \mathrm{l}$ of digestion solution followed by the addition of $20 \mu \mathrm{l}$ of proteinase $\mathrm{K}$, vortexed and incubated for three $\mathrm{h}$ at 56 ${ }^{\circ} \mathrm{C}$. After incubation, RNase-A solution $(20 \mu \mathrm{l})$ was added, vortexed gently and left for ten min at room temperature. Lysis solution $(200 \mu \mathrm{l})$ was added and vortexed for a short interval till a homogenous mixture was obtained. In the following step, $400 \mu \mathrm{l}$ of $50 \%$ ethanol was added to the lysate, thoroughly mixed, transferred to a column containing a collection tube and centrifuged for a min at $6000 \times \mathrm{g}$. The flow-through was discarded, the column was transferred to a new collection tube $(2 \mathrm{ml})$ and washed with washing buffers. Finally, the genomic DNA was eluted by addition of $200 \mu \mathrm{L}$ of elution buffer to the column, incubated for two min at room temperature and centrifuged for $1 \mathrm{~min}$ at $8000 \times \mathrm{g}$ to collect the DNA. The eluted DNA was stored at $-20^{\circ} \mathrm{C}$ for downstream use.

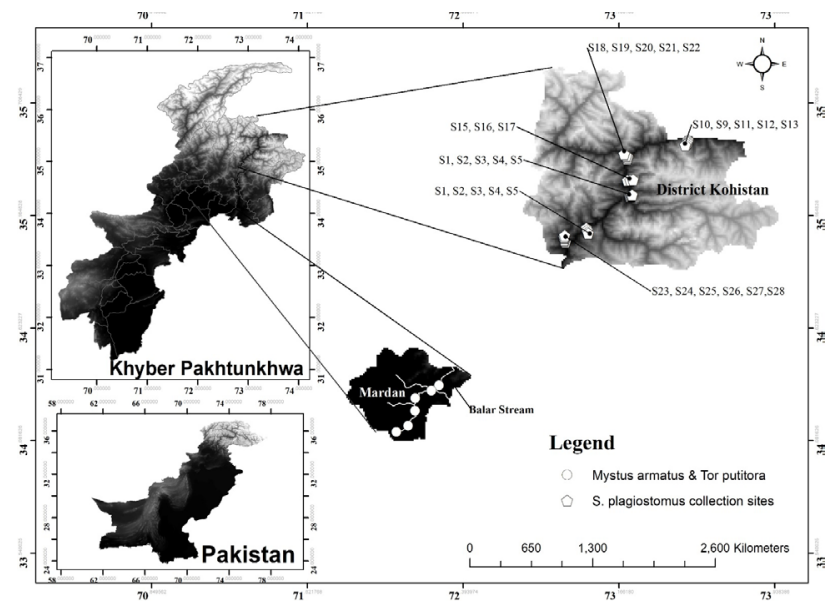

Fig. 1. Map showing different sampling sites of collected fish spp.

Nucleotide sequences for COI gene of Shizothorax spp. were downloaded from NCBI, aligned in Bio-Edit $\mathrm{v}$ 7.0.5 and on the basis of highly conserved regions a pair of primer (forward FP1: CTAACCACAAAGACATTGGTACCC, reverse RP1; CCTGAGTAGTGGC TACAACGTGAG) was designed for the amplification of $\mathrm{CO} 1$ gene. For the amplification of $\mathrm{COl}$ gene of Tor and Mystus species, a pair of universal primer (F1: TCAACCAACCACA AAGACATTGGCAC and R1: TAGACTTCTGGGTGGCCAAAGAATCA) were used as reported previously (Ward et al., 2005). Dream Taq Green PCR Master Mix (2X) (Thermo-Scientific) was used for amplification of the $\mathrm{CO} 1$ gene. Each PCR reaction (25 $\mu 1)$ contained $12.5 \mu$ l Master mix (2X), forward and revese primers ( $1 \mu \mathrm{l}$ each), $2 \mu \mathrm{l}$ template DNA and $8.5 \mu \mathrm{l}$ PCR water. The reaction mixture was thoroughly mixed and quickly transferred to a thermocycler (HT, ILF, UK). The parameters for amplification of $\mathrm{CO} 1$ gene for Schizothorax spp. were set to initial denaturation at $95{ }^{\circ} \mathrm{C}$ for $2 \mathrm{~min}$ followed by 35 cycles of amplification (denaturation at 95 ${ }^{\circ} \mathrm{C}$ for $30 \mathrm{sec}$, annealing at $58^{\circ} \mathrm{C}$ for $45 \mathrm{sec}$ and extension at $72{ }^{\circ} \mathrm{C}$ for $45 \mathrm{sec}$ ) followed by final extension at $72{ }^{\circ} \mathrm{C}$ for 4 min. Similar parameters were followed for Tor and Mystus spp. except the annealing temperature was set to $54^{\circ} \mathrm{C}$ and the final extension lasted for $10 \mathrm{~min}$. The amplified target DNA was loaded parallel to $1 \mathrm{~Kb}$ ladder marker (Thermoscientific) onto an agarose gel $(1.5 \% \mathrm{~W} / \mathrm{V})$ containing ethidium bromide, electrophoresed and visualized by a transilluminator (UVP Bio-Doc, California, USA) for confirmation of the expected product. The confirmed PCR products (640 bp, $431 \mathrm{bp}$, and $648 \mathrm{bp}$ for Schizothorax spp., T. putitora and M. armatus) were cleaned by using a purification kit (GeneClean II from Qbiogene) following the manufacturer's protocol. The final purified products were sent to Macrogen (Korea) in order to determine its nucleotide sequences.

After sequencing, the obtained crude sequences were trimmed by using Bio-Edit v. 7 (Hall, 1999) to remove any contamination from primers. The obtained trimmed sequences were scanned in NCBI GeneBank through BLAST against non-redundant nucleotide database for homologous sequences deposited for the same gene (Altschul et al., 1990). The obtained sequences and homologous sequences were aligned and edited using GeneDoc v. 5.1 (Nicholas et al., 1997) and Bio-Edit version 7 (Hall, 1999). Aligned sequences were used to make a phylogenetic tree by using neighbor joining (NJ) method in MEGA v. X (Molecular Evolutionary Genetics Analysis) (Kumar et al., 2018). The bootstrap confidence intervals for each branching pattern were calculated from 1000 replicates by resampling (Tamura et al., 2013). The values of average sequence divergence and nucleotide composition were calculated by using MEGA v. X.

\section{RESULTS}

During this study, two areas of KP were targeted for the collection of fish species of economic importance posing taxonomic ambiguities during identification and characterization. Preliminary identification of all the collected specimens were done by using dichotomous keys and fin formula which have confirmed Schizothorax spp. as $S$. plagiostomus from river Indus in District Kohistan, Tor spp. as T. putitora and T. macrolepus and Mystus spp. as $M$. armatus from Balar stream in District Mardan.

Fish samples collected from river Indus were observed with elongated, silvery golden colored, heavy spots, minute 
scales, rounded abdomen, mouth with inferior suctoral disc, two pairs of rostral and maxillary short barbells and blunt snout. Lateral line was complete having dorsal fin toward anterior wherase its last unbranched fin ray was serrated internally. Specific features of the fins were thoroughly recorded according to the extracted fin formula (D III, 7; P 16-17; V 10; A II, 5; C19- 20; L1 105) (Jayaram, 1981; Kullander et al., 1999), and the specimens were identified as $S$. plagiostomus. Specimens of Tor spp. collected from Balar stream were morphologically identified by applying the meristic method to count different structures in the selected organs of the fish body and to extract the fin formula (Jayaram, 1981; Kullander et al., 1999). On the basis of fin formula, collected specimens were identified as T. putitora (D IV, 8; A III, 5; P 17-18; V I 8; L1 25-28) and T. macrolepis (D IV, (7-9); P15-18; V I, (7-8); A II, (5-6); Ll (24-28)) (Jayaram, 1981; Talwar and Jhingran, 1991; Mirza, 2004). Similarly, the morphological description of $M$. armatus was also made through meristic method by applying the fin formula (D II, 7; P I, 9; VI, 5; A III, 8; C 19) (Jayaram, 2010)

The amplified DNA from each specimen collected in each location was sequenced and deposited to NCBI genebank (accession numbers: Schizothorax spp., MK587530, MK430415, MK627707, MK559419, MK421950, MK430414, MK640501, MK645807, MK421950, MK430414, MK795688, MK883813, MT020509, MT020510, MT020511, MT020512, MT020513, MT020514, MT020515, MT020516, MT020517, MT020518, MT020519, MT020520; T. putitora, MN515234; M. armatus, MN715235). After trimming, each of the $C O 1$ sequences yielded an average of $640 \mathrm{bp}$ sequence for $S$. plagiostomus (Table I), $431 \mathrm{bp}$ sequence for T. putitora (Table II) and $648 \mathrm{bp}$ sequence for M. armatus (Table III). The COI sequence analysis revealed the average nucleotide frequencies for S. plagiostomus as $28.6 \%$ T, 28.2\% C, 25.7\% A and 17.5\% G (Table I). In case of T. putitora $28.91 \%$ T, $26.72 \%$ C, $27.45 \%$ A and $16.79 \%$ G (Table II), while M. armatus has shown a percent ratio of nucleotides as $29.78 \% \mathrm{~T}, 27.47 \% \mathrm{C}, 26.54 \% \mathrm{~A}$ and $16.2 \% \mathrm{G}$ (Table III). The obtained sequences and their homologous sequences, collected after BLAST, were subjected to multiple sequence alignment that showed highly conserved regions among these sequences and with those collected from NCBI GenBank deposited for same species from neighbor countries like China and India.

In the case of Schizothorax spp. the average sequence divergence was estimated 0.029 to 0.07 showing high sequence diversity among specimens morphologically identified as $S$. plagiostomus (Table IV). In case of Tor spp. all obtained sequences were found identical and were considered as a single sequence. The average sequence divergence was estimated 0.002 to 0.007 among Tor spp. showing highest sequence similarity with other $T$. putitora sequences (Table V). These findings negated the existence and distribution of T. macrolepus in KP. In case of Mystus spp. all obtained sequences were also identical and therefore considered as a single sequence. For M. armatus, the NCBI database was searched with no sequence similarities thus the present work was the first attempt using COI partial gene for species delineation and sequence addition to the database. The average sequence divergence of $M$. armatus with other Mystus spp. retrieved from NCBI was estimated as 0.003 to 0.142 (Table VI).

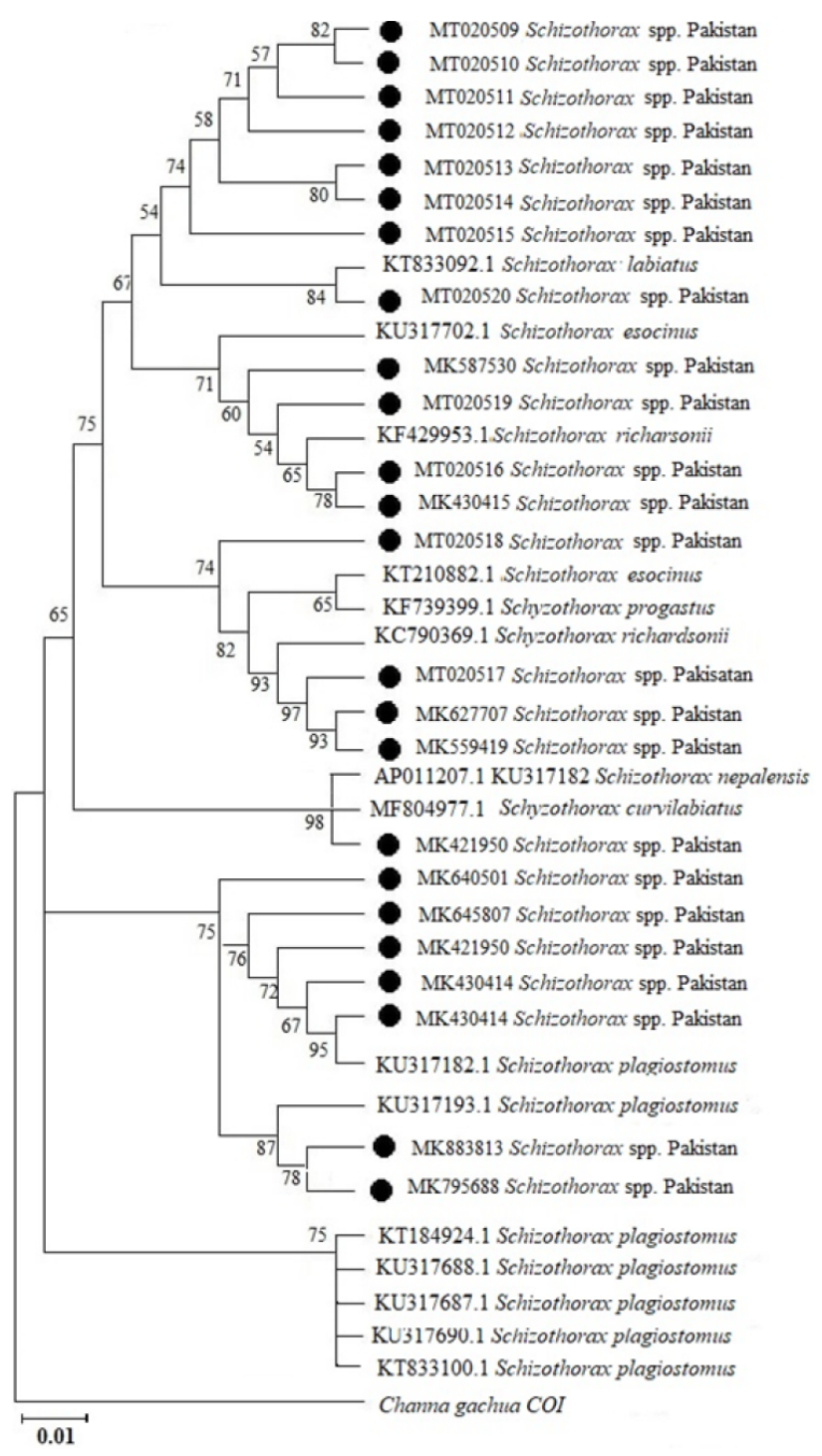

Fig. 2. Phylogenetic tree constructed using NJ method based on COI sequences shows the evolutionary relationship of obtained sequences from Schizothorax spp. 


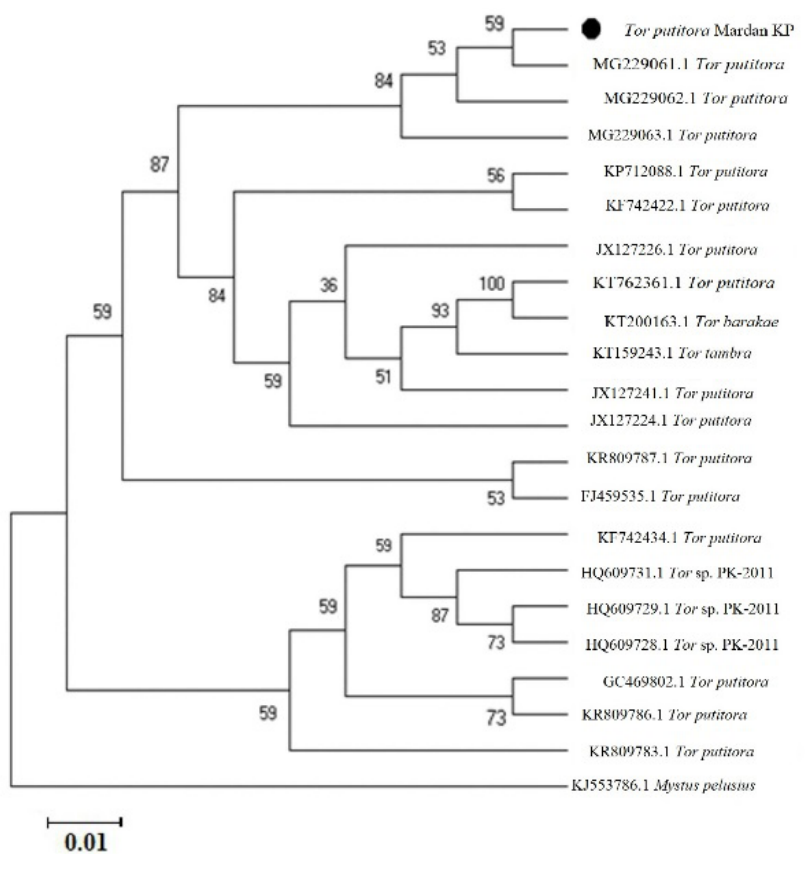

Fig. 3. Phylogenetic tree based on $\mathrm{COI}$ sequences showing the evolutionary relationship of Tor spp. constructed by using $\mathrm{NJ}$ method.



$\stackrel{\longmapsto}{0.01}$

Fig. 4. Phylogenetic tree based on $\mathrm{COI}$ sequences showing the evolutionary relationship of Mystus spp. constructed by using NJ method.

The phylogenetic analysis was separately performed for each genus using obtained sequences in MEGA v. X. In case of $S$. plagiostomus, the COI sequences clustered into various clades and sub-clades belonging to different species in the genus Schizothorax (Fig. 2). In case of T. putitora, $C O I$ sequence clustered closely with $T$. putitora reported from Azad Jammu and Kashmir forming a distinct clade which distantly clustered with other $T$. putitora sequences reported from India and China (Fig. 3). In the present study, the COI sequence of $M$. armatus were clustered with $M$. bleekari from India. Furthermore, BLAST search has confirmed an addition of a novel $M$. armatus sequence to the NCBI database in the present study (Fig. 4).

\section{DISCUSSION}

Numerous fish species have been misidentified due to their taxonomic similarities with several other species belonging to the same genus (Chu and Chen, 1989; Shan et al., 2000; Hebert et al., 2003; ZiMing and JunXing, 2004; Hebert and Gregory, 2005). Therefore, molecular studies are essential to accurately identify these fishes at species level. Species belong to Schizothorax genus are mainly inhabiting Himalayan and sub-Himalayan region, T. putitora naturally distributed throughout the rivers (and associated reservoirs) of the South Himalayan drainage from Pakistan (Jha et al., 2018). The Mystus spp. have been reported from the south and southeast Asian countries including Bangladesh, India, Myanmar, Pakistan, Sri Lanka, Indonesia, Malaysia, Singapore, Thailand and Vietnam (Ng, 2010). The Tor spp. and Mystus spp. have been proved to be very useful for its taxonomy as well as for the investigation of its evolutionary pattern (Ahmad et al., 2014; Bashir et al., 2016). The present study is the first attempt to explore the species identification and genetic diversity of Schizothorax spp. inhabiting river Indus and its tributaries in District Kohistan and T. putitora and $M$. armatus in Balar Stream District Mardan KP, Pakistan. Collective approach using traditional keys and molecular method were adopted to explore species delineation and phylogenetic relationships.

The DNA barcoding based on COI divergence has been aimed to build an association between molecular and morphological taxonomists (Hebert and Gregory, 2005). The molecular characterization of S. plagiostomus, $M$. armatus and T. putitora applied during this study proved authentic and reliable for species level identification. It is noteworthy to mention that all the collected species of Schizothorax, Tor, and Mystus were preliminary characterized on the basis of their morphological identification as $S$. plagiostomus, T. putitora, T. macrolepus and $M$. armatus. However, the molecular characterization revealed high species diversity within the genus Schizothorax including S. labiatus, Schizothorax nepalensis, Schizothorax progastus, Schizothorax curvilabiatus, 
Table I. Average composition of AT/GC of Schizothorax spp. sequences collected from different localities.

\begin{tabular}{|c|c|c|c|c|c|c|c|c|}
\hline Collection site & COI sequences & Latitude & Longitude & $\mathbf{T}(\mathbf{U})$ & $\mathbf{C}$ & $\mathbf{A}$ & $\mathbf{G}$ & Total \\
\hline Jalkot Nallah & S 6 & 35.25602 & 73.219306 & 28.7 & 27.8 & 25.9 & 17.7 & 640 \\
\hline Jalkot Nallah & S 21 & 35.25686 & 73.222654 & 28.8 & 27.9 & 25.8 & 17.5 & 640 \\
\hline Jalkot Nallah & S 9 & 35.2583 & 73.225873 & 28.8 & 28 & 25.7 & 17.5 & 640 \\
\hline Jalkot Nallah & S 15 & 35.26096 & 73.227611 & 27.9 & 28.7 & 24.1 & 19.4 & 640 \\
\hline Jalkot Nallah & S 2 & 35.26299 & 73.230723 & 28.7 & 28 & 25.7 & 17.6 & 640 \\
\hline Gul Bagh Nallah & S 28 & 35.10315 & 73.002975 & 28.8 & 28 & 25.7 & 17.5 & 640 \\
\hline Gul Bagh Nallah & S 22 & 35.09397 & 73.00761 & 28.9 & 28 & 25.6 & 17.5 & 640 \\
\hline Gul Bagh Nallah & S 16 & 35.08392 & 73.009177 & 28.8 & 27.9 & 25.7 & 17.6 & 640 \\
\hline Gul Bagh Nallah & S 23 & 35.07798 & 73.012803 & 28.6 & 28 & 25.7 & 17.6 & 640 \\
\hline Sazin Gah Nallah & S 20 & 35.5274 & 73.507279 & 28.9 & 27.8 & 25.7 & 17.6 & 640 \\
\hline Sazin Gah Nallah & S 1 & 35.5219 & 73.50567 & 27.8 & 30.8 & 25 & 16.3 & 640 \\
\hline Sazin Gah Nallah & S 27 & 35.51519 & 73.504618 & 28.9 & 27.9 & 25.9 & 17.3 & 640 \\
\hline Sazin Gah Nallah & S 17 & 35.5099 & 73.498653 & 25.4 & 31.5 & 24.1 & 19 & 640 \\
\hline Sazin Gah Nallah & S 14 & 35.50281 & 73.493482 & 28.7 & 27.8 & 25.8 & 17.6 & 640 \\
\hline Barseen Nallah & S 13 & 35.33321 & 73.207202 & 28.8 & 28.1 & 25.8 & 17.4 & 640 \\
\hline Barseen Nallah & S 12 & 35.3337 & 73.22145 & 28.9 & 27.8 & 26 & 17.2 & 640 \\
\hline Barseen Nallah & S 18 & 35.33685 & 73.235098 & 28.1 & 28.9 & 26.4 & 16.6 & 640 \\
\hline Kandia Nallah & S 10 & 35.43698 & 73.206497 & 28.7 & 27.9 & 25.8 & 17.7 & 640 \\
\hline Kandia Nallah & S 5 & 35.44264 & 73.208558 & 28.8 & 28.1 & 25.8 & 17.4 & 640 \\
\hline Kandia Nallah & S 26 & 35.44841 & 73.206456 & 28.6 & 28 & 25.9 & 17.5 & 640 \\
\hline Kandia Nallah & S 11 & 35.45229 & 73.200662 & 28.7 & 28.3 & 25.7 & 17.3 & 640 \\
\hline Kandia Nallah & S 8 & 35.45998 & 73.19019 & 28.8 & 28 & 25.9 & 17.3 & 640 \\
\hline Dubair Nallah & S 19 & 35.03751 & 72.898914 & 28.8 & 27.9 & 25.6 & 17.7 & 640 \\
\hline Dubair Nallah & S 3 & 35.04324 & 72.894365 & 29 & 27.8 & 25.8 & 17.4 & 640 \\
\hline Dubair Nallah & S 24 & 35.04877 & 72.894086 & 28.9 & 28 & 25.6 & 17.5 & 640 \\
\hline Dubair Nallah & S 26 & 35.05601 & 72.892563 & 28.7 & 28.3 & 25.7 & 17.3 & 640 \\
\hline Dubair Nallah & S 25 & 35.06114 & 72.893936 & 28.7 & 28 & 25.8 & 17.5 & 640 \\
\hline Dubair Nallah & $\mathrm{S} 4$ & 35.06758 & 72.896403 & 28.8 & 27.9 & 25.9 & 17.5 & 640 \\
\hline Average & & & & 28.6 & 28.2 & 25.7 & 17.5 & 640 \\
\hline
\end{tabular}

Table II. Average composition of AT/GC of T. putitora sequences collected from different localities.

\begin{tabular}{|c|c|c|c|c|c|c|c|c|}
\hline Collection Site & COI Sequence & Latitude & Longitude & $\mathbf{T}$ & $\mathbf{A}$ & $\mathbf{C}$ & $\mathbf{G}$ & Total \\
\hline \multirow[t]{4}{*}{ Rustam } & T. putitora & 34.34825 & 72.27282 & 28.91 & 27.45 & 26.72 & 16.79 & 431 \\
\hline & T. putitora & & & 28.91 & 27.45 & 26.72 & 16.79 & 431 \\
\hline & T. putitora & & & 28.91 & 27.45 & 26.72 & 16.79 & 431 \\
\hline & T. putitora & & & 28.91 & 27.45 & 26.72 & 16.79 & 431 \\
\hline \multirow[t]{3}{*}{ Chargulli } & T. putitora & 34.323102 & 72.235972 & 28.91 & 27.45 & 26.72 & 16.79 & 431 \\
\hline & T. putitora & & & 28.91 & 27.45 & 26.72 & 16.79 & 431 \\
\hline & T. putitora & & & 28.91 & 27.45 & 26.72 & 16.79 & 431 \\
\hline \multirow[t]{2}{*}{ Bakhshali } & T. putitora & 34.28614 & 72.155027 & 28.91 & 27.45 & 26.72 & 16.79 & 431 \\
\hline & T. putitora & & & 28.91 & 27.45 & 26.72 & 16.79 & 431 \\
\hline \multirow[t]{2}{*}{ Bala Garhi } & T. putitora & 34.226454 & 72.154324 & 28.91 & 27.45 & 26.72 & 16.79 & 431 \\
\hline & T. putitora & & & 28.91 & 27.45 & 26.72 & 16.79 & 431 \\
\hline \multirow[t]{2}{*}{ Toru } & T. putitora & 34.154009 & 72.120519 & 28.91 & 27.45 & 26.72 & 16.79 & 431 \\
\hline & T. putitora & & & 28.91 & 27.45 & 26.72 & 16.79 & 431 \\
\hline \multirow[t]{2}{*}{ Magam Nullah } & T. putitora & 34.124292 & 72.062368 & 28.91 & 27.45 & 26.72 & 16.79 & 431 \\
\hline & T. putitora & & & 28.91 & 27.45 & 26.72 & 16.79 & 431 \\
\hline Average & - & - & - & 28.91 & 27.45 & 26.72 & 16.79 & 431 \\
\hline
\end{tabular}


Table III. Average composition of AT/GC of Mystus spp. sequences collected from different localities.

\begin{tabular}{|c|c|c|c|c|c|c|c|c|}
\hline Collection Site & COI Sequence & Latitude & Longitude & $T$ & $\mathbf{A}$ & $\mathbf{C}$ & $\mathbf{G}$ & Total \\
\hline \multirow[t]{2}{*}{ Rustam } & M. armatus & 34.34825 & 72.27282 & 29.78 & 26.54 & 27.47 & 16.2 & 648 \\
\hline & M. armatus & & & 29.78 & 26.54 & 27.47 & 16.2 & 648 \\
\hline \multirow[t]{4}{*}{ Chargulli } & M. armatus & 34.323102 & 72.235972 & 29.78 & 26.54 & 27.47 & 16.2 & 648 \\
\hline & M. armatus & & & 29.78 & 26.54 & 27.47 & 16.2 & 648 \\
\hline & M. armatus & & & 29.78 & 26.54 & 27.47 & 16.2 & 648 \\
\hline & M. armatus & & & 29.78 & 26.54 & 27.47 & 16.2 & 648 \\
\hline \multirow[t]{3}{*}{ Bakhshali } & M. armatus & 34.28614 & 72.155027 & 29.78 & 26.54 & 27.47 & 16.2 & 648 \\
\hline & M. armatus & & & 29.78 & 26.54 & 27.47 & 16.2 & 648 \\
\hline & M. armatus & & & 29.78 & 26.54 & 27.47 & 16.2 & 648 \\
\hline \multirow[t]{2}{*}{ Bala Garhi } & M. armatus & 34.226454 & 72.154324 & 29.78 & 26.54 & 27.47 & 16.2 & 648 \\
\hline & M. armatus & & & 29.78 & 26.54 & 27.47 & 16.2 & 648 \\
\hline \multirow[t]{2}{*}{ Toru } & M. armatus & 34.154009 & 72.120519 & 29.78 & 26.54 & 27.47 & 16.2 & 648 \\
\hline & M. armatus & & & 29.78 & 26.54 & 27.47 & 16.2 & 648 \\
\hline \multirow[t]{2}{*}{ Magam Nullah } & M. armatus & 34.124292 & 72.062368 & 29.78 & 26.54 & 27.47 & 16.2 & 648 \\
\hline & M. armatus & & & 29.78 & 26.54 & 27.47 & 16.2 & 648 \\
\hline Average & & & & 29.78 & 26.54 & 27.47 & 16.2 & 648 \\
\hline
\end{tabular}

Table IV. Average evolutionary divergence between obtained sequences and homologous sequences of Schizothorax spp. from NCBI.

\begin{tabular}{lllll}
\hline Species & $\begin{array}{l}\text { NCBI-GenBank acces- } \\
\text { sion No }\end{array}$ & Regions & $\begin{array}{l}\text { Specimen sequences from River } \\
\text { Indus }\end{array}$ & $\begin{array}{l}\text { Average evolution- } \\
\text { ary divergence }\end{array}$ \\
\hline S. plagiostomus & KU317693.1 & AJK Pakistan & S 1 FWP- S28 FWP & 0.03 \\
S. plagiostomus & KT833100.1 & China & S 1 FWP- S28 FWP & 0.031 \\
S. plagiostomus & KU317682.1 & AJK Pakistan & S 1 FWP- S28 FWP & 0.031 \\
S. plagiostomus & KT184924.1 & Dir Pakistan & S 1 FWP- S28 FWP & 0.031 \\
S. plagiostomus & KU317690.1 & AJK Pakistan & S 1 FWP- S28 FWP & 0.033 \\
S. plagiostomus & KU317688.1 & AJK Pakistan & S 1 FWP- S28 FWP & 0.033 \\
S. plagiostomus & KU317687.1 & AJK Pakistan & S 1 FWP- S28 FWP & 0.033 \\
S. esocinus & KT210882.1 & Dir Pakistan & S 1 FWP- S28 FWP & 0.032 \\
S. progastus & KF739399.1 & India & S 1 FWP- S28 FWP & 0.032 \\
S. labiatus & KT833092.1 & China & S 1 FWP- S28 FWP & 0.032 \\
S. esocinus & KU317702.1 & AJK Pakistan & S 1 FWP- S28 FWP & 0.036 \\
S. nepalensis & AP011207.1 & Nepal & S 1 FWP- S28 FWP & 0.039 \\
S. richardsonii & KU695220.1 & India & S 1 FWP- S28 FWP & 0.03 \\
S. richardsonii & KF429953.1 & India & S 1 FWP- S28 FWP & 0.029 \\
S. curvilabiatus & MF804977.1 & China & S 1 FWP- S28 FWP & 0.07 \\
S. richardsonii & KC790369.1 & India & S 1 FWP- S28 FWP & 0.033 \\
\hline
\end{tabular}


Table V. Average evolutionary divergence between obtained sequences and homologous sequences of $T$. putitora from NCBI.

\begin{tabular}{lllll}
\hline Species & $\begin{array}{l}\text { NCBI-GenBank } \\
\text { accession No }\end{array}$ & Regions & $\begin{array}{l}\text { Specimen Sequences from } \\
\text { Balar Stream }\end{array}$ & $\begin{array}{l}\text { Average Evolutionary } \\
\text { Divergence }\end{array}$ \\
T. putitora & MG229063.1 & Muzaffarabad, PK & T. putitora & 0.002 \\
T. putitora & MG229062.1 & Muzaffarabad, PK & T. putitora & 0.002 \\
T. putitora & MG229061.1 & Muzaffarabad, PK & T. putitora & 0.002 \\
T. putitora & KP712088.1 & China & T. putitora & 0.007 \\
T. putitora & KF742434.1 & India & T. putitora & 0.002 \\
T. putitora & KR809783.1 & India & T. putitora & 0.002 \\
T. putitora & GQ469803.1 & India & T. putitora & 0.002 \\
T. putitora & GQ469802.1 & India & T. putitora & 0.002 \\
T. putitora & KR809786.1 & India & T. putitora & 0.002 \\
\hline
\end{tabular}

Table VI. Average evolutionary divergence between obtained sequences and homologous sequences of $M$. aramatus from NCBI.

\begin{tabular}{|c|c|c|c|c|}
\hline Species & $\begin{array}{l}\text { NCBI-GenBank acces- } \\
\text { sion No }\end{array}$ & Regions & $\begin{array}{l}\text { Specimen sequences from Balar } \\
\text { Stream }\end{array}$ & $\begin{array}{l}\text { Average evolutionary } \\
\text { divergence }\end{array}$ \\
\hline M. bleekeri & KJ936764.1 & India & M. armatus & 0.008 \\
\hline M. bleekeri & КT364779.1 & Bangladesh & M. armatus & 0.003 \\
\hline M. albolineatus & KF824808.1 & India & M. armatus & 0.060 \\
\hline M. albolineatus & KF824811.1 & India & M. armatus & 0.092 \\
\hline M. ngasep & KJ909390.1 & India & M. armatus & 0.130 \\
\hline M. cavasius & KT762365.1 & Bangladesh & M. armatus & 0.136 \\
\hline M. tengara & KT762366.1 & Bangladesh & M. armatus & 0.142 \\
\hline
\end{tabular}

Schizothorax richardsonii and Schizothorax esocinus. In the present study, the estimated average sequence divergence confirmed the presence of $M$. armatus showing sequence similarity with $M$. bleekari reported from Bangladesh and India. This similarity with $M$. bleekari might be due to the unavailability of $M$. armatus sequences in the NCBI database. In the case of Tor spp. the specimen's preliminary identified as T. putitora and T. macrolepus through morphological features, however, molecular approach has confirmed their species signature as $T$. putitora only. Similar studies have been reported showing T. macrolepis misidentified as T. putitora from river Indus (Chu and Chen, 1989; Shan et al., 2000).

All the obtained sequences were $\mathrm{A}+\mathrm{T}$ rich which is in agreement with previous reports for $S$. plagiostomus (Johns and Avise, 1998). For S. plagiostomus average A+T contents of obtained sequences in the present study were found as $54.2 \%$ and $45.8 \%$ as $\mathrm{G}+\mathrm{C}$ contents (Ward et al., 2005; Lakra et al., 2011; Vineesh et al., 2013; Bashir et al., 2016). For T. putitora $\mathrm{A}+\mathrm{T}$ contents were calculated as $56.35 \%$ and $43.5 \%$ as $\mathrm{G}+\mathrm{C}$ which is accordance with previous reports (Esa et al., 2008). In case of M. armatus the $\mathrm{A}+\mathrm{T}$ contents were $56.33 \%$ and $43.67 \%$ for $\mathrm{G}+\mathrm{C}$ and is in accordance (45.4\%) with the individuals of the same order (i.e. Siluriformes). Also, a strong correlation between the GC contents for $C O I$ gene and entire mitochondrial genome have been already reported (Min and Hickey, 2007).

According to the phylogenetic analysis, our obtained sequences clustered with various Schizothorax spp. (Fig. 2). The genetic diversity showed that the collected Schizothorax spp. have evolutionary relationship with Schizothorax spp. from India, China and Nepal (Chandra et al., 2012). The genetic diversity of $T$. putitora species collected from the Balar Stream showed closest genetic similarity with $T$. putitora previously reported from Azad Jammu Kashmir, Pakistan and India (Laskar et al., 2013; Yang et al., 2015) (Fig. 3). M. armatus collected from the Balar Stream of Mardan District showed close sequence resemblance with the species $M$. blekeeri from India and 
Bangladesh (Fig. 3).

The phylogenetic analysis of the COI gene during the present study has confirmed various Schizothorax species in the study area mostly misidentified as $S$. plagiostomus. In case of Tor and Mystus spp., the collected specimens were identified as $T$. putitora and $M$. armatus respectively, by the application of DNA barcoding through the use of $\mathrm{COI}$ gene. This is in agreement to the finding of Hebert et al. (2003) who reported that phylogenetic analysis through $\mathrm{COI}$ barcoding is an effective tool for the identification of an organism at species level.

\section{CONCLUSIONS}

This is the first ever molecular approach for the identification of Schizothorax species in river Indus and $T$. putitora and $M$. armatus species in Balar stream Mardan, KP, Pakistan. To the best of our knowledge, the $M$. armatus COI gene sequence is reported for the first time during this study. This study has proved the authenticity of the molecular approach using COI barcoding in the identification of Schizothorax, Tor and Mystus spp. Further molecular studies are highly recommended to investigate fish species of economic importance commonly inhabiting various streams and rivers in Pakistan.

\section{ACKNOWLEDGMENTS}

The authors appreciate the financial support provided by Higher Education Commission (HEC) and Pakistan Science Foundation (PSF) for ongoing research facilities in the laboratory.

\section{Statement of conflict of interest}

The authors have declared no conflict of interests.

\section{REFERENCES}

Ahmad, S.M., Bhat, F.A., Balkhi, M.U.H. and Bhat, B.A., 2014. Mitochondrial DNA variability to explore the relationship complexity of Schizothoracine (Teleostei: Cyprinidae). Genetica, 14: 507-516. https://doi.org/10.1007/s10709-014-9797-y

Ali, F., Khan, M.Q., Anjum, M.Z. and Khattak, I., 2018. Toxic effect of atrazine herbicide on the hematological indices of snow carp (Schizothorax plagiostomus): An indigenous fish species of economic importance. Fresenius environ. Bull., 27: 3075-3080.

Altschul, S.F., Gish, W., Miller, W., Myers, E.W. and Lipman, D.J., 1990. Basic local alignment search tool. J. mol. Biol., 215: 403-410. https://doi.
org/10.1016/S0022-2836(05)80360-2

Arnot, D.E., Roper, C. and Bayoumi, R.A., 1993. Digital codes from hypervariable tandemly repeated DNA sequences in the Plasmodium falciparum circumsporozoite gene can genetically barcode isolates. Mol. Biochem. Parasitol., 61: 1524. https://doi.org/10.1016/0166-6851(93)90154-P

Azam,. A. and Shafique, M., 2017. Agriculture in Pakistan and its impact on economy: A review. Int. J. Advan. Sci. Technol., 103: 47-60. https://doi. org/10.14257/ijast.2017.103.05

Bashir, A., Bisht, B.S., Mir, J.I., Patiyal, R.S. and Kumar, R., 2016. Morphometric variation and molecular characterization of snow trout species from Kashmir valley, India. Mitochond. DNA Part A., 27: 4492-4497. https://doi.org/10.3109/194017 36.2015.1101537

Chandra, S., Barat, A., Singh, M., Singh, B.K. and Matura, R., 2012. DNA bar-coding of Indian cold water fishes of genus Schizothorax (family: Cyprinidae) from Western Himalaya. World $J$. Fish. Mar. Sci., 4: 430-435.

Chen, Z. and Yang. J., 2004. A new species of genus Tor from Yunan China (Teleostei: Cyprinidae). Environ. Biol. Fishes, 70: 185-191. https://doi. org/10.1023/B:EBFI.0000029360.57048.92

Chu, X.L. and Chen, Y.R., 1989. Yunnan Yu Lei Zhi (The fishes of Yunnan, China) Part I. Cyprinidae., Science Press, Beijing.

Esa, Y.B., Siraj, S.S., Daud, S.K., Rahim, K.A.A., Japning, J.R.R. and Tan, S.G., 2008. Mitochondrial DNA diversity of Tor tambroides Valenciennes (Cyprinidae) from five natural populations in Malaysia. Zool. Stud., 47: 360-367.

Ferraris, C.J., 2007. Checklist of catfishes, recent and fossil (Osteichthyes: Siluriformes), and catalogue of siluriform primary types. Zootaxa, 1418: 1-628. https://doi.org/10.11646/zootaxa.1418.1.1

Floyd, R., Abebe, E., Papert, A. and Blaxter, M., 2002. Molecular barcodes for soil nematode identification. Mol. Ecol., 11: 839-850. https://doi. org/10.1046/j.1365-294X.2002.01485.x

Hall, T.A., 1999. Bioedit: A user-friendly biological sequence alignment editor and analysis program for windows 95/98/nt. Paper presented at the nucleic acids symposium series. 41: 95-98.

Hebert, P.D., Cywinska, A. and Ball, S.L., 2003. Biological identifications through DNA barcodes. Proc. R. Soc. Lond. B. Biol. Sci., 270: 313-321. https://doi.org/10.1098/rspb.2002.2218

Hebert, P.D. and Gregory, T.R., 2005. The promise of DNA barcoding for taxonomy. Syst. Biol., 54: 852- 
859. https://doi.org/10.1080/10635150500354886

Hora, S.L., 1931. On two small collection of fishes from Burma. Rec. Indian Mus., 33: 1-2.

Hora, S.L., 1936. On a further collection of fish from Naga Hills. Rec. Indian Mus., 38: 317-331.

Hubert, N. and Hanner, R., 2015. DNA barcoding, species delineation and taxonomy: A historical perspective. DNA Barcodes, 3: 44-58. https://doi. org/10.1515/dna-2015-0006

Hubert, N., Hanner, R., Holm, E., Mandrak, N.E., Taylor, E., Burridge, M., Watkinson, D., Dumont, P., Curry, A., Bentzen, P. and Zhang, J., 2008. Identifying Canadian freshwater fishes through DNA barcodes. PLoS One, 3: 1-8. https://doi. org/10.1371/journal.pone.0002490

Jayaram, K.C., 2010. The freshwater fishes of the Indian region. Narendra Publication Company., New Delhi, pp. 616.

Jayaram, K.C., 1981. Freshwater fishes of India, Pakistan, Bangladesh, Burma and Sri Lanka. Zoological Survey of India.

Jayaram, K.C. and Sanyal, A., 2003. A taxonomic revision of the fishes of the genus Mystus scopoli (family: Bagridae): Records of the zoological survey of India. Zool. Surv. India, 207: 1-136.

Jha, B.R., Rayamajhi, A., Dahanukar, N., Harrison, A. and Pinder, A.C., 2018. Tor putitora. The IUCN Red List of Threatened Species, 2018.

Jhingran, V.G., 1991. Fish and Fisheries of India. Hindustan Publ. Co., New Delhi. pp. 727.

Johns, G.C. and Avise, J.C., 1998. Tests for ancient species flocks based on molecular phylogenetic appraisals of sebastes rockfishes and other marine fishes. Evolution, 52: 1135-1146. https://doi. org/10.1111/j.1558-5646.1998.tb01840.x

Khan, M.Q., Anjum, M.Z., Akhter, S., Khattak, I. and Ali, A., 2018. Diet composition and seasonal fluctuations in the feeding habit of snow barbel (Schizothorax plagiostomus) in River Indus, Pakistan. Acta Sci. Vet., 46: 1-8. https://doi. org/10.22456/1679-9216.82439

Kochzius, M., 2009. The future of fisheries science in North America: Trends in fishery genetics. Springer, 31: 453-493. https://doi.org/10.1007/978-1-40209210-7 24

Kullander, S.O., Fang, F., Delling, B. and Ahlander, E., 1999. The fishes of the Kashmir Valley, River Jhelum, Kashmir Valley: Impacts on the aquatic environment. Swedmar Göteborg, pp. 99-167.

Kumar, S., Stecher, G., Li, M., Knyaz, C. and Tamura, K., 2018. MEGA X: Molecular evolutionary genetics analysis across computing platforms. Mol.
Biol. Evol., 35: 1547-1549. https://doi.org/10.1093/ molbev/msy096

Lakra, W.S., Verma, M.S., Goswami, M., Lal, K.K., Mohindra, V., Punia, P., Gopalakrishnan, A., Singh, K.V., Ward, R.D. and Hebert, P., 2011. DNA barcoding Indian marine fishes. Mol. Ecol. Resour., 11: 60-71. https://doi.org/10.1111/j.17550998.2010.02894.x

Laskar, B.A., Bhattacharjee, M.J., Dhar, B., Mahadani, P., Kundu, S. and Ghosh, S.K., 2013. The species dilemma of northeast Indian mahseer (Actinopterygii: Cyprinidae): DNA barcoding in clarifying the riddle. PLoS One, 8: 1-11. https://doi. org/10.1371/journal.pone.0053704

Mcclelland, J., 1839. Indian cyprinidae. Asiat Res., 19: 217-471.

McCusker, M.R., Denti, D., Van Guelpen, L., Kenchington, E. and Bentzen, P., 2013. Barcoding Atlantic Canada's commonly encountered marine fishes. Mol. Ecol. Resour., 13: 177-188. https://doi. org/10.1111/1755-0998.12043

Min, X.J. and Hickey, D.A., 2007. DNA barcodes provide a quick preview of mitochondrial genome composition. PLoS One, 2: 325. https://doi. org/10.1371/journal.pone.0000325

Mir, F.A., Mir, J.I. and Chandra, S., 2013. Phenotypic variation in the snow trout Schizothorax richardsonii (Gray, 1832) (Actinopterygii: Cypriniformes: Cyprinidae) from the Indian Himalayas. Contrib. Zool., 82: 115-122. https://doi. org/10.1163/18759866-08203001

Mirza, M.R. and Mirza, Z.S., 2014. Longitudinal zonation in the fish fauna of the Indus River in Pakistan. Biologia, 60: 149-152.

Mirza, M.R., 2004. Freshwater fishes in Pakistan, $2^{\text {nd }}$ edition. Urdu Science Board, Lahore, Pakistan.

Tahir, M. and Akhtar, S., 2016. Services of DNA barcoding in different fields. Mitochond. DNA, 27: 4463-4474. https://doi.org/10.3109/19401736.201 5.1089572

Ng, H.H., 2010. Wallago attu. The IUCN Red List of Threatened Species, version 2014. pp. 3.

Nicholas, K.B., Nicholas, H.B. and Deerfield, D.W., 1997. GeneDoc: Analysis and visualization of genetic variation. EMBnet News, 4: 14.

Rafique, M. and Khan, N.U.H., 2012. Distribution and status of significant freshwater fishes of Pakistan. Rec. Zool. Surv. Pakistan, 21: 90-95.

Shan, X.H., Lin, R.D., Yue, P.Q. and Chu, X.L., 2000. Barbinae. In: Fauna Sinica, Osteichthyes, Cypriniformes III (ed. P.Q. Yue). Science Press, Beijing, China. pp. 3-170. 
Talwar, P.K. and Jhingran, A.G., 1991. Inland fisheries of India and adjacent countries. Vol. I \& II, pp. 1-1158.

Tamura, K., Stecher, G., Peterson, D., Filipski, A. and Kumar, S., 2013. MEGA 6 molecular evolutionary genetics analysis version 6.0. Mol. Biol. Evol., 30: 2725-2729. https://doi.org/10.1093/molbev/ mst197

Vineesh, N., Mohitha, C., Bineesh, K.K., Kumar, R.G., Gopalakrishnan, A. and Basheer, V.S., 2013. DNA barcoding and taxonomic notes on the genus Macolor (Perciformes: Lutjanidae) from Indian waters. J. Ocean Sci. Found,., 13: 16-26.

Wang, Z.D., Guo, Y.S., Liu, X.M., Fan, Y.B. and Liu, C.W., 2012. DNA barcoding South China Sea fishes. Mitochondrial DNA., 23: 405-410. https:// doi.org/10.3109/19401736.2012.710204

Ward, R.D., Zemlak, T.S., Innes, B.H., Last, P.R. and
Hebert, P.D., 2005. DNA barcoding Australia's fish species. Philos. T. R. Soc. B., 360: 1847-1857. https://doi.org/10.1098/rstb.2005.1716

Wong, E.H.K. and Hanner, R.H., 2008. DNA barcoding detects market substitution in North American seafood. Fd. Res. Int., 41: 828-837. https://doi. org/10.1016/j.foodres.2008.07.005

Yang, L., Sado, T., Hirt, M.V., Pasco-Viel, E., Arunachalam, M., Li, J., Wang, X., Freyhof, J., Saitoh, K., Simons, A.M. and Miya, M., 2015. Phylogeny and polyploidy: Resolving the classification of cyprinine fishes (Teleostei: Cypriniformes). Mol. Phylog. Evol., 85: 97-116. https://doi.org/10.1016/j.ympev.2015.01.014

Ziming, C. and Junxing, Y., 2004. A new species of the genus Tor from Yunnan, China (Teleostei: Cyprinidae).Environ.Biol.Fish,70:185-191.https:// doi.org/10.1023/B:EBFI.0000029360.57048.92 